\title{
Review \\ Usefulness of Magnetic Mallet in Oral Surgery and Implantology: A Systematic Review
}

\author{
Francesco Bennardo ${ }^{1, * \mathbb{D}}$, Selene Barone ${ }^{1}$, Camillo Vocaturo ${ }^{2}$, Ludovica Nucci ${ }^{3} \mathbb{D}$, Alessandro Antonelli ${ }^{1, *} \mathbb{D}$ \\ and Amerigo Giudice ${ }^{1}(\mathbb{D}$
}

1 School of Dentistry, Department of Health Sciences, Magna Graecia University of Catanzaro, Viale Europa, 88100 Catanzaro, Italy; selene.barone@studenti.unicz.it (S.B.); a.giudice@unicz.it (A.G.)

2 Private Practice, Via Nicola Serra 80, 87100 Cosenza, Italy; camillovocaturo@gmail.com

3 Multidisciplinary Department of Medical-Surgical and Dental Specialties, University of Study of Campania, Luigi Vanvitelli, 80138 Naples, Italy; ludovica.nucci@unicampania.it

* Correspondence: fbennardo92@gmail.com (F.B.); antonellicz@gmail.com (A.A.); Tel.: +39-346-180-2826 (F.B.); $+39-392-231-8180$ (A.A.)

check for updates

Citation: Bennardo, F.; Barone, S.; Vocaturo, C.; Nucci, L.; Antonelli, A.; Giudice, A. Usefulness of Magnetic Mallet in Oral Surgery and Implantology: A Systematic Review. J. Pers. Med. 2022, 12, 108. https:// doi.org/10.3390/jpm12010108

Academic Editor: Luca Testarelli

Received: 21 December 2021

Accepted: 11 January 2022

Published: 14 January 2022

Publisher's Note: MDPI stays neutral with regard to jurisdictional claims in published maps and institutional affiliations.

Copyright: (c) 2022 by the authors. Licensee MDPI, Basel, Switzerland. This article is an open access article distributed under the terms and conditions of the Creative Commons Attribution (CC BY) license (https:// creativecommons.org/licenses/by/ $4.0 /)$.

\begin{abstract}
This systematic review aimed to answer the question: "Is the use of magnetic mallet effective in oral and implant surgery procedures in terms of tissue healing, surgery outcome, and complication rate compared to traditional instruments?" A literature search of PubMed, Scopus, and Web of Science databases (articles published until 1 October 2021) was conducted, in accordance with the PRISMA statement, using the keywords "magnetic mallet", "electric mallet", "oral surgery", "implantology", and "dental implant". Of 252 articles, 14 were included in the review (3 for teeth extraction, and 11 for implant dentistry). Out of a total of 619 dental extractions (256 patients) performed with the magnetic mallet (MM), no complications were reported. Implants inserted totaled 880 (525 patients): 640 in the MM groups (382), and 240 in control groups (133). The survival rate of implants was $98.9 \%$ in the MM groups, and $95.42 \%$ in the control groups. Seven patients experienced benign paroxysmal positional vertigo after implant surgery, all in control groups. Results are not sufficient to establish the effectiveness of MM in oral and implant surgery procedures. Randomized controlled trials with a large sample size are needed.
\end{abstract}

Keywords: dental implants; alveolar ridge augmentation; sinus floor augmentation; tooth extraction

\section{Introduction}

Alveolar bone resorption after tooth extraction occurs for both physiological and iatrogenic reasons [1]. Several factors have been related to bone resorption: a patient's general health and behavior, pre-operative condition, tooth type and location, and postoperative management [2]. Though no extraction technique is completely atraumatic, it has been reported to influence the extent of alveolar bone resorption: conventional tooth extraction techniques, involving the use of elevators, periotomes, and forceps, operate on the principle of socket expansion, and will, therefore, traumatize the alveolar bone to some extent, which is often associated with higher tissue trauma and increased post-extraction bone loss [3]. The loss of the bundle bone is secondary to periodontal ligament fibers and vessels interruption, clot instability, and soft tissue collapse [4]. A traumatic extraction may also lead to other complications, such as fracture of a bony wall, poor healing due to a compromised blood supply, and soft tissue damage [1].

Alveolar ridge remodeling occurs most rapidly in the first six months after tooth extraction, but bone resorption continues throughout life at a slower rate [5]. Preservation of an adequate volume of soft and hard tissues is necessary to obtain functional and aesthetic stability of prosthetic restorations, whether removable or fixed, including dental implants [6]. Several minimally-invasive tooth extraction techniques using new technolo- 
gies (vertical extraction, piezoelectric, magneto-dynamic) have been described. However, there is no evidence of lower alveolar bone resorption [7].

Residual alveolar ridges' features affect the opportunity of prosthetic rehabilitation with dental implants [8]. Successful osseointegration of dental implants depends on multiple factors, including bone quantity and quality, primary implant stability, fixtures design, and surface characteristics [9]. A reduced amount of bone requires reconstruction or innovative surgical techniques [10]. In cases of horizontal defects, the ridge can be expanded, or wedge implants placed [11]. In cases of vertical bone defects, sinus floor elevation (in the maxilla) or short implants are available techniques [12,13].

In recent decades, companies have proposed numerous innovative surgical devices for oral surgery and implantology. These devices mainly work through laser, piezoelectric, and magneto-dynamic technologies. Nevertheless, there is a lack of clinical evidence regarding their application for dental surgery in some cases.

A timely evaluation of new surgical techniques is necessary to prevent widespread adoption with insufficient evidence, and promote innovation supported by sufficient evidence [14]. The evaluation of medical innovation is challenging because surgical technique, approach, and instrumentation continue to evolve as novel techniques are used in practice [1].

Magneto-dynamic technology exploits the physical principles of electromagnetism to apply controlled forces on a body while minimizing the time of impact. The control and steadiness of the applied forces make the procedures safe for patients and surgeons. William Bonwill patented the first electrified dental mallet in 1873: it was used for cavities' gold filling [15].

In the 21st century, the Magnetic Mallet (MM) device (Meta Ergonomica, Milan, Italy) exploits magneto-dynamic technology in dental surgery. The MM is composed of a handpiece energized by a power control device, delivering forces by the timing of application. Different inserts could be attached to the handpiece, which pushes a shock wave on its tip according to the surgical procedures. Four force modes are available: $75,90,130$, and $260 \mathrm{daN}$. The time of impact is $80 \mu \mathrm{s}[16,17]$.

Several authors describe the application of MM in dental extractions, crestal sinus lift, ridge expansion, implant placement, and implant site preparation (osseodensification). However, it is not clear whether there is scientific evidence for these MM applications.

The main objective of this study was to conduct a systematic review of the literature to determine whether the use of MM is effective in oral and implant surgery procedures, and to consider the possible role of MM in reducing failures and complications.

\section{Materials and Methods}

The authors followed the criteria established in the Preferred Reporting Items for Systematic Reviews and Meta-Analyses (PRISMA) guidelines for this review [18].

\subsection{PICO Question}

"Is the use of magnetic mallet effective in oral and implant surgery procedures in terms of tissue healing, surgery outcome, and complication rate compared to traditional instruments?"

\subsection{Search Strategy}

An electronic literature search was performed using the following databases: Medline (using PubMed), Scopus, and Web of Science. Articles published up to 1 October 2021 were included. The keywords used were "magnetic mallet", "electric mallet", "oral surgery", "implantology", and "dental implant", using the Boolean operators "AND", "OR". 


\subsection{Inclusion and Exclusion Criteria}

The following inclusion criteria were applied: (1) any original publication in the English language, (2) studies conducted on humans, (3) the use of the MM for surgical procedures.

The following exclusion criteria were applied: (1) in vitro studies; (2) experimental animal studies; (3) radiological studies without clinical evaluation; (4) cadaver studies; (5) the use of the MM for implant placement only; (6) literature reviews, letters, editorials, doctoral theses, or abstracts.

The reference list of review articles was analyzed to search for other articles not found in the electronic literature search.

\subsection{Selection of the Studies}

The manuscripts selected included prospective studies, retrospective studies, and observational studies. Two authors (FB, SB) conducted database searches independently, and discrepancies were resolved in a consensus meeting with a third reviewer (AA).

\subsection{Data Extraction}

Data was extracted by two reviewers independently (FB, CV). Disagreement was subject to a new evaluation with a third reviewer (AG). The variables extracted from the studies were the following: study design, type of intervention (dental extraction, implant site preparation, ridge expansion, sinus lift), number of patients and sites treated, follow-up duration, outcomes, complications.

\subsection{Data Analysis}

Data in the included studies was analyzed with descriptive statistics: total number of cases, percentage of outcome variables, etc. Data was subdivided by type of intervention. If none of the included studies were set up as a randomized clinical study, the meta-analysis would not be performed. An independent researcher (LN) performed descriptive statistical analysis with the STATA software program (STATA, Release 14; STATA Corporation, College Station, TX, USA).

\section{Results}

The results of the literature search are presented in the PRISMA flow diagram (Figure 1). 

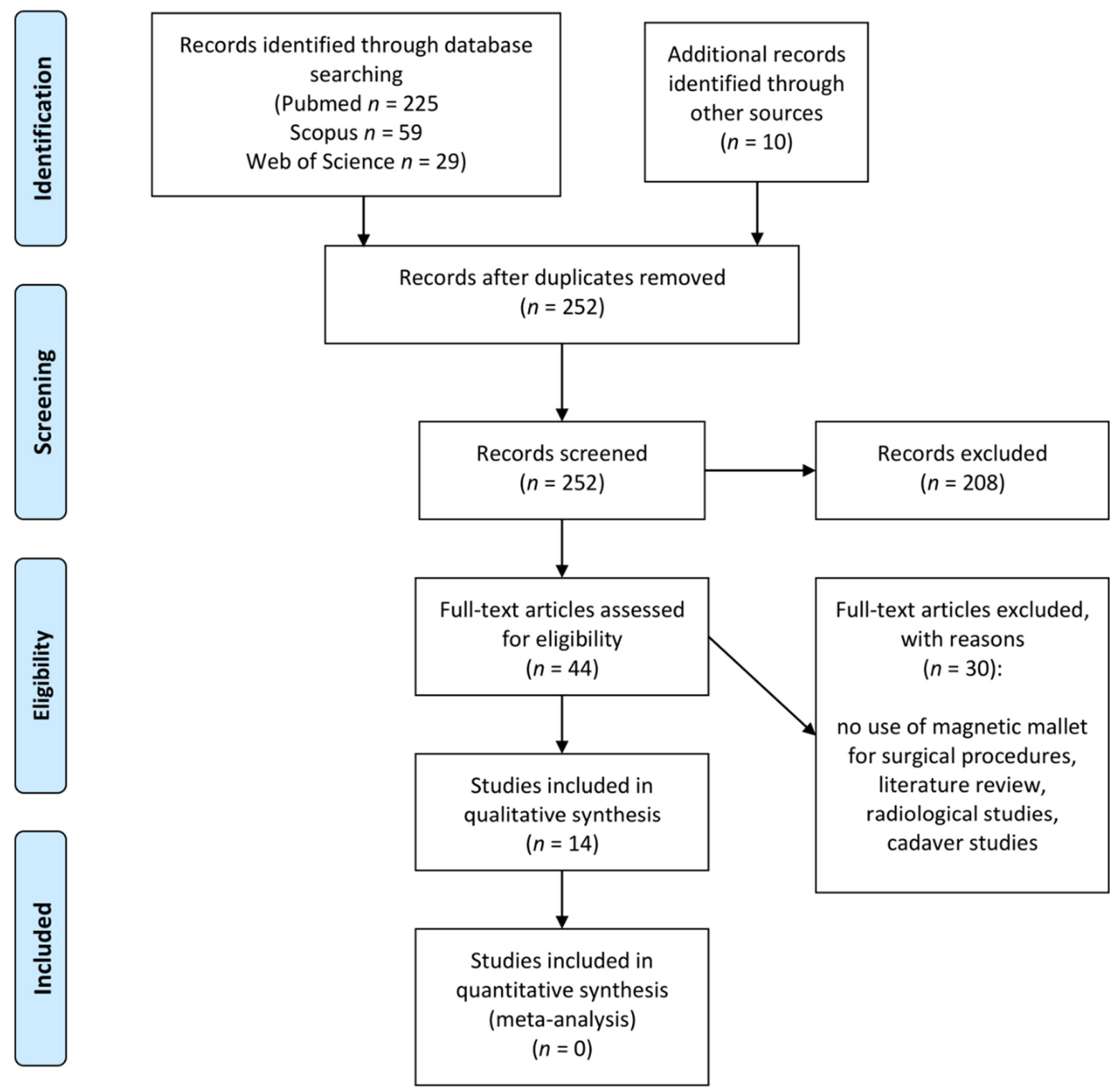

Figure 1. PRISMA flow diagram.

\subsection{Study Selection}

The search strategy yielded records (225 from PubMed, 59 from Scopus, 29 from Web of Science); and 10 additional articles were identified through a hand search. After the removal of duplicates, 252 records remained. After title and abstract screening, 44 articles were identified for full-text retrieval and analysis. Of these, $30 \mathrm{did}$ not meet the inclusion criteria (articles not in English language, literature reviews, no use of magnetic mallet), and 1 article's full-text was not retrieved. The remaining 14 articles were included in the systematic review; the included papers are listed in Table 1 according to study design, and type of intervention. None of the included studies were set up as a randomized clinical trial; therefore, none were included in the quantitative synthesis. 
Table 1. Specific features and outcomes of the studies included.

\begin{tabular}{|c|c|c|c|c|c|c|c|}
\hline Reference & $\begin{array}{c}\text { Type of } \\
\text { Intervention }\end{array}$ & $\begin{array}{l}\text { Study } \\
\text { Design }\end{array}$ & $\begin{array}{c}\text { Number of } \\
\text { Patients } \\
\text { Treated }\end{array}$ & $\begin{array}{c}\text { Number of Sites } \\
\text { (Implants/Teeth) } \\
\text { Treated }\end{array}$ & Follow-Up & Outcomes & Complications \\
\hline $\begin{array}{l}\text { Crespi et al., } \\
2012 \text { A [19] }\end{array}$ & Sinus lift & Prospective & $\begin{array}{l}40 \mathrm{MM} \\
40 \mathrm{CTR}\end{array}$ & $\begin{array}{l}60 \mathrm{MM} \\
60 \mathrm{CTR}\end{array}$ & $6,12,24 \mathrm{~m}$ & $\begin{array}{c}\text { Survival rate of } \\
98.33 \% \text { (both } \\
\text { groups) }\end{array}$ & $\begin{array}{l}2 \mathrm{BPPV} \text { in CTR } \\
\text { group }\end{array}$ \\
\hline $\begin{array}{l}\text { Crespi et al., } \\
2012 \text { B [20] }\end{array}$ & $\begin{array}{l}\text { Implant site } \\
\text { preparation }\end{array}$ & Prospective & $\begin{array}{l}25 \mathrm{MM} \\
25 \mathrm{CTR}\end{array}$ & $\begin{array}{l}69 \mathrm{MM} \\
69 \text { CTR }\end{array}$ & $6,12,24 \mathrm{~m}$ & $\begin{array}{c}\text { Survival rate of } \\
97.1 \%(\mathrm{MM}) \text { and } \\
92.75 \%(\mathrm{CTR})\end{array}$ & $\begin{array}{l}2 \mathrm{BPPV} \text { in CTR } \\
\text { group }\end{array}$ \\
\hline $\begin{array}{l}\text { Crespi et al., } \\
2013 \text { A [21] }\end{array}$ & Sinus lift & Prospective & 32 & 70 & $2,4,12,24 \mathrm{~m}$ & $\begin{array}{c}\text { Survival rate of } \\
98.57 \%\end{array}$ & - \\
\hline $\begin{array}{l}\text { Crespi et al., } \\
2013 \text { B [22] }\end{array}$ & $\begin{array}{l}\text { Implant site } \\
\text { preparation }\end{array}$ & Prospective & $\begin{array}{l}18 \mathrm{MM} \\
18 \mathrm{CTR}\end{array}$ & $\begin{array}{l}25 \mathrm{MM} \\
25 \mathrm{CTR}\end{array}$ & $6,12,24 \mathrm{~m}$ & $\begin{array}{l}\text { Survival rate of } \\
96 \% \text { (both groups) }\end{array}$ & $\begin{array}{c}2 \mathrm{BPPV} \text { in CTR } \\
\text { group }\end{array}$ \\
\hline $\begin{array}{l}\text { Crespi et al., } \\
2014 \text { A [23] }\end{array}$ & $\begin{array}{l}\text { Ridge } \\
\text { expansion }\end{array}$ & Prospective & $\begin{array}{l}23 \mathrm{MM} \\
23 \mathrm{CTR}\end{array}$ & $\begin{array}{l}59 \mathrm{MM} \\
59 \mathrm{CTR}\end{array}$ & $6,12,24 \mathrm{~m}$ & $\begin{array}{c}\text { Survival rate of } \\
100 \%(\mathrm{MM}) \text { and } \\
96.61 \%(\mathrm{CTR})\end{array}$ & $\begin{array}{c}1 \mathrm{BPPV} \text { in CTR } \\
\text { group }\end{array}$ \\
\hline $\begin{array}{l}\text { Crespi et al., } \\
2014 \text { B [24] }\end{array}$ & $\begin{array}{c}\text { Dental } \\
\text { extraction }\end{array}$ & Retrospective & 156 & 427 & - & $\begin{array}{l}\text { No fracture or } \\
\text { loss of cortical } \\
\text { bone plate }\end{array}$ & - \\
\hline $\begin{array}{l}\text { Crespi et al., } \\
2015 \text { [25] }\end{array}$ & $\begin{array}{c}\text { Ridge } \\
\text { expansion }\end{array}$ & Retrospective & 36 & 93 & $6,12,24 \mathrm{~m}$ & $\begin{array}{c}\text { Survival rate of } \\
98.92 \%\end{array}$ & - \\
\hline $\begin{array}{l}\text { Crespi et al., } \\
2016 \text { A [26] }\end{array}$ & $\begin{array}{l}\text { Implant site } \\
\text { preparation }\end{array}$ & Prospective & 40 & 40 & $36 \mathrm{~m}$ & $\begin{array}{c}\text { Survival rate of } \\
100 \%\end{array}$ & - \\
\hline $\begin{array}{l}\text { Crespi et al., } \\
2016 \text { B [27] }\end{array}$ & $\begin{array}{l}\text { Implant site } \\
\text { preparation }\end{array}$ & Prospective & 57 & 84 & $36 \mathrm{~m}$ & $\begin{array}{c}\text { Survival rate of } \\
100 \%\end{array}$ & - \\
\hline $\begin{array}{l}\text { Crespi et al., } \\
2017 \text { [28] * }\end{array}$ & $\begin{array}{l}\text { Dental } \\
\text { extraction }\end{array}$ & Prospective & 53 & 145 & $3 \mathrm{~m}$ & $\begin{array}{c}\text { No signs of } \\
\text { inflamed tissue or } \\
\text { exposed bone }\end{array}$ & - \\
\hline $\begin{array}{c}\text { Menchini- } \\
\text { Fabris GB, et al. } \\
2020 \text { A [29] * }\end{array}$ & $\begin{array}{l}\text { Dental } \\
\text { extraction }\end{array}$ & Retrospective & 47 & 47 & $24-36 \mathrm{~m}$ & $\begin{array}{l}\text { No postoperative } \\
\text { complications }\end{array}$ & - \\
\hline $\begin{array}{l}\text { Menchini- } \\
\text { Fabris GB, et al. } \\
2020 \text { B [30] }\end{array}$ & Sinus lift & Observational & $\begin{array}{l}29 \mathrm{MM} \\
27 \mathrm{CTR}\end{array}$ & $\begin{array}{l}29 \mathrm{MM} \\
27 \mathrm{CTR}\end{array}$ & $36 \mathrm{~m}$ & $\begin{array}{c}\text { Survival rate of } \\
100 \%(\mathrm{MM}) \text { and } \\
92.6 \%(\mathrm{CTR})\end{array}$ & - \\
\hline $\begin{array}{l}\text { Crespi et al. } \\
2021 \text { [31] }\end{array}$ & Sinus lift & Retrospective & 40 & 40 & $36 \mathrm{~m}$ & $\begin{array}{c}\text { Survival rate } \\
100 \%\end{array}$ & - \\
\hline $\begin{array}{l}\text { Bruschi et al. } \\
2021 \text { [32] }\end{array}$ & Sinus lift & Retrospective & 52 & 71 & $\begin{array}{l}\text { 9-66 m (mean } \\
29.8 \mathrm{~m})\end{array}$ & $\begin{array}{c}\text { Survival rate } \\
98.6 \%\end{array}$ & - \\
\hline
\end{tabular}

Legend: MM, magnetic mallet; CTR, control group; $\mathrm{m}$, months; BPPV, benign paroxysmal positional vertigo

* MM was not the main topic investigated in the manuscript.

\subsection{Magnetic Mallet in Teeth Extraction}

Three studies related to the use of the magnetic mallet for teeth extraction were included: one retrospective clinical study on the utility of the magnetic mallet in dental extraction [22], one prospective study on dimensional changes of fresh sockets with reactive soft tissue preservation after tooth extraction performed with the magnetic mallet [27], and one retrospective clinical study on the effect of different timings of implant insertion on the bone remodeling volume around patients' maxillary single implants after tooth extraction performed with the magnetic mallet [23]. A total of 256 patients were recruited in the studies considered. Dental extractions totaled 619: no complications related to teeth extraction performed with the magnetic mallet were reported in these studies (no fracture or loss of cortical bone plate, no signs of inflamed tissue or exposed bone). Statistical analysis was not performed considering the lack of control groups.

\subsection{Magnetic Mallet in Implant Surgery}

Eleven studies related to the use of the magnetic mallet in implant surgery were included: two prospective clinical studies, two retrospective clinical studies, and one observational study on sinus lift performed with the magnetic mallet $[19,28,29,31,32]$; four prospective clinical studies on implant site preparation performed with the magnetic mallet $[20,21,24,30]$; and one prospective clinical study and one retrospective clinical study on ridge expansion performed with the magnetic mallet $[25,26]$. 
A total of 525 patients were recruited in the studies considered: 382 underwent implant surgery performed with the magnetic mallet, and 133 underwent implant surgery performed with standard techniques. Implants inserted totaled 880: 640 in the magnetic mallet groups, and 240 in control groups. The survival rate of implants after 9-66 months was $98.9 \%$ in the magnetic mallet groups, and $95.42 \%$ in the control groups.

No patients treated in the magnetic mallet groups experienced benign paroxysmal positional vertigo (BPPV), whereas seven patients in the control groups showed this complication after sinus lift (2), implant site preparation (4), and ridge expansion (1) performed with osteotomes pushed by the hand mallet.

Statistical analysis was not performed considering the non-comparability of the studies' data included in this review.

\section{Discussion}

Fourteen articles were included in this systematic review: three related to the use of the magnetic mallet for teeth extraction, and eleven related to the use of MM in implant surgery, for a total of 256 and 525 treated patients, respectively.

Results related to surgical procedures performed with MM highlighted no complications related to teeth extraction, an implant survival rate of 98.9\% after 9-66 months of follow-up, and no patients experienced BPPV.

Considering that none of the included studies were set up as a randomized clinical trial, these results are not sufficient to establish a superior effectiveness of the magnetic mallet compared to standard procedures.

\subsection{Magnetic Mallet in Teeth Extraction}

The trauma sustained by the periodontium during tooth extraction changes considerably depending on the technique used, ranging from the extraction of a single-rooted tooth using periotomes, elevators, and forceps, to the reflection of a mucoperiosteal flap and bone removal. Bone trauma is difficult to avoid, as the principle of tooth extraction is socket expansion, and even a successful extraction using elevators or periotomes will traumatize alveolar bone to some extent. Although no extraction technique can be completely atraumatic, several minimally-invasive tooth extraction techniques using new technologies (vertical extraction, piezoelectric, magneto-dynamic) have been described $[7,33]$.

The literature analysis highlighted a few studies concerning the use of MM for dental extractions, but only one retrospective clinical study entirely focused on this topic. Crespi et al. reported the extraction of 427 hopeless teeth in 156 patients using MM. They observed no soft tissue healing complication, fracture, or loss of cortical bone plate. The authors described how the axial movements applied on the blade's tip detached the root from the surrounding alveolar bone, reducing trauma to adjacent bone, and avoiding damages to gingival tissues [22]. In the other studies examined, authors did not report complications in teeth extractions performed with $\mathrm{MM}[23,27]$.

Considering the advantages described, the use of MM could simplify the procedures for obtaining stem cells of dental origin [34,35].

In 2009, another device that exploited the advantages of atraumatic extractions of the periotome with mechanized speed was brought to the market without success under the name of "Powertome" [36]. On the contrary, the MM has been very successful, and using the same patent, a device dedicated to dental extractions, called "Easyroot", has recently been introduced [37].

In the last two years, following the outbreak of the severe acute respiratory syndrome coronavirus 2 (SARS-CoV-2) pandemic, recommendations have been issued to avoid the risk of contagion, which includes minimizing the production of aerosols during dental procedures [38-40]. Recently, Chien et al. presented an aerosolizing reducing technique for the extraction of impacted mandibular third molars using a chisel and mallet. The use of the chisel requires tapping with a mallet on the handle to separate the tooth from surrounding 
bone. This technique can cause unnecessary discomfort for the patient, and may cause BPPV. Furthermore, this technique may also be uncomfortable for the surgeon [41].

Given the concern of aerosol-generating techniques and exposure to SARS-CoV-2, the MM could be used for surgical teeth extraction as a way of minimizing aerosol exposure (authors' opinion).

\subsection{Magnetic Mallet in Implant Surgery}

Innovative devices and technologies to reduce morbidity, biological, and surgical times are an intense research topic in implant dentistry. Implant-prosthetic rehabilitations are a routine treatment, but a minimal amount of bone, both vertical and horizontal, is necessary at implant placement. Several techniques were described to increase the amount of bone before or simultaneously with fixture insertion [42,43]. These surgical procedures involve using various tools, such as surgical burs, saws, laser, or piezoelectric devices. In the crestal sinus lift and ridge-splitting procedures, after corticotomy, the osteotome/chisel is pushed by a hand mallet to provoke a greenstick fracture of the bone with a spacemaking effect that could be filled with biomaterials or with dental implants at the same time. This technique was also used for implant site preparation. However, the tapping of osteotomies/chisels with a hand mallet can induce BPPV in some cases. The MM handpiece imparts a longitudinal movement along the central axis of the osteotome/chisel that acts upon and forces the internal wall of the hole outward radially, resulting in controlled fracture and displacement of the cortical bone, and greater bone tissue density along the walls $[25,28,30]$. Furthermore, the MM is currently the gold standard for blade- and wedge-implant insertion [11,44].

The literature analysis highlighted several studies concerning the use of MM for implant surgery, but focused on different types of interventions.

In 2012 and 2013, Crespi et al. reported the successful insertion of 130 dental implants after sinus floor elevation performed with $\mathrm{MM}$ in 72 patients, with a survival rate of $98 \%$ after two years of follow-up. The results of both prospective studies allowed the authors to evaluate $\mathrm{MM}$ as a fast and accurate device in crestal sinus lift, with minor patient discomfort compared to the traditional technique with a hand mallet and osteotomes [28,31]. In the other studies examined, the authors confirmed the validity of MM in crestal sinus lift $[19,29,32]$.

In 2014 and 2015, Crespi et al. reported the successful insertion of 152 dental implants after ridge expansion performed with MM in 59 patients, with a survival rate above $98 \%$ after two years of follow-up. The authors stated that segmental ridge split with MM represents a safe, predictable, and comfortable surgical procedure, and it does not lead to bone injury or overheating $[25,26]$.

Crespi et al., between 2012 and 2016, conducted four prospective clinical studies on implant site preparation performed with MM, reporting successful insertion of 218 dental implants in 140 patients, with a survival rate not less than $96 \%$ after $24-36$ months of follow-up $[20,21,24,30]$.

The survival rate of implants placed on patients treated with MM was $98.9 \%$ after 9-66 months of follow-up, and $95.42 \%$ in the control groups. No patients treated with MM in the included studies experienced BPPV, probably due to the application of controlled forces in very short, defined intervals. In contrast, seven patients in the control groups experienced BPPV after sinus lift (2), ridge expansion (1), and implant site preparation (4) performed with osteotomes pushed by a hand mallet. Besides, there are biases in the articles examined in the review, concerning the type of study, the presence or absence of control groups, the characteristics of the patients included, and the dissimilar protocols used (flap or flapless surgery, delayed or immediate implant insertion).

Feher et al. evaluated resonance frequency analysis (RFA) values of fixtures placed in condensed bone with implant site preparation performed with $\mathrm{MM}$ after drilling a pilot hole of $2.2 \mathrm{~mm}$ in diameter, and $8 \mathrm{~mm}$ in depth, both in edentulous ridges and in fresh sockets. Their main finding is that mean RFA values correlated with peak insertion torque 
(PIT) in both uncondensed and condensed bone in edentulous jaws. Vice versa, in fresh extraction sockets, bone condensation led to a loss of correlation between RFA and PIT: implant site preparation with MM led to higher mean RFA, but not higher PIT values. The effects of bone condensation are somewhat complex, and need cautious interpretation and further investigations [45].

\section{Conclusions}

The use of MM may be helpful in oral and implant surgery procedures because of its safety, predictability, speed, and comfort of use. Considering limitations (no studies eligible for meta-analysis, no randomized studies, no multicentric studies, small samples, different protocols), the results of this systematic review are not sufficient to prove MM's effectiveness in dental surgery.

Further randomized controlled studies are needed to establish whether the use of MM could, on the one hand, significantly reduce the complication rate after oral surgery procedures, and, on the other, improve tissue healing and long-time implant survival.

Author Contributions: Conceptualization, F.B. and A.G.; methodology, F.B. and S.B.; software, S.B. and L.N.; validation, F.B. and A.G.; formal analysis, F.B., C.V., S.B., and A.A.; investigation, F.B. and C.V.; resources, A.A. and L.N.; data curation, F.B.; writing-original draft preparation, F.B., C.V., and A.A.; writing-review and editing, F.B., S.B., L.N., and A.G.; supervision, A.G. All authors have read and agreed to the published version of the manuscript.

Funding: This research received no external funding.

Institutional Review Board Statement: Not applicable.

Informed Consent Statement: Not applicable.

Data Availability Statement: The data presented in this study are available on request from the corresponding author.

Conflicts of Interest: The authors declare no conflict of interest.

\section{References}

1. Hong, B.; Bulsara, Y.; Gorecki, P.; Dietrich, T. Minimally invasive vertical versus conventional tooth extraction: An interrupted time series study. J. Am. Dent. Assoc. 2018, 149, 688-695. [CrossRef]

2. Kalk, W.; De Baat, C. Some factors connected with alveolar bone resorption. J. Dent. 1989, 17, 162-165. [CrossRef]

3. Schmidlin, P.R.; Jung, R.E.; Schug, J. Prevention of alveolar ridge resorption after tooth extraction-A review. Schweiz. Mon. Zahnmed. 2004, 114, 328-336.

4. Hansson, S.; Halldin, A. Alveolar ridge resorption after tooth extraction: A consequence of a fundamental principle of bone physiology. J. Dent. Biomech. 2012, 3, 1758736012456543. [CrossRef]

5. Samiksha, G.; Saumyendra, V.S.; Deeksha, A. Residual ridge resorption-A review of etiology. Polymorphism 2019, 2, 107-113.

6. Atieh, M.A.; Alsabeeha, N.H.M.; Tawse-Smith, A.; Duncan, W.J. Piezoelectric versus conventional implant site preparation: A systematic review and meta-analysis. Clin. Implant. Dent. Relat. Res. 2018, 20, 261-270. [CrossRef] [PubMed]

7. Saund, D.; Dietrich, T. Minimally-invasive tooth extraction: Doorknobs and strings revisited! Dent. Update 2013, 40, 325-330. [CrossRef] [PubMed]

8. Attanasio, F.; Antonelli, A.; Brancaccio, Y.; Averta, F.; Figliuzzi, M.M.; Fortunato, L.; Giudice, A. Primary Stability of Three Different Osteotomy Techniques in Medullary Bone: An in Vitro Study. Dent. J. 2020, 8, 21. [CrossRef]

9. Giudice, A.; Bennardo, F.; Antonelli, A.; Barone, S.; Wagner, F.; Fortunato, L.; Traxler, H. Influence of clinician's skill on primary implant stability with conventional and piezoelectric preparation techniques: An ex-vivo study. J. Biol. Regul. Homeost. Agents 2020, 34, 739-745. [PubMed]

10. Antonelli, A.; Bennardo, F.; Brancaccio, Y.; Barone, S.; Femiano, F.; Nucci, L.; Minervini, G.; Fortunato, L.; Attanasio, F.; Giudice, A. Can Bone Compaction Improve Primary Implant Stability? An In Vitro Comparative Study with Osseodensification Technique. Appl. Sci. 2020, 10, 8623. [CrossRef]

11. Vercellotti, T.; Troiano, G.; Oreglia, F.; Lombardi, T.; Gregorig, G.; Morella, E.; Rapani, A.; Stacchi, C. Wedge-Shaped Implants for Minimally Invasive Treatment of Narrow Ridges: A Multicenter Prospective Cohort Study. J. Clin. Med. 2020, 9, 3301. [CrossRef] [PubMed]

12. Palacios, J.A.V.; Garcia, J.J.; Caramês, J.M.M.; Quirynen, M.; da Silva Marques, D.N. Short implants versus bone grafting and standard-length implants placement: A systematic review. Clin. Oral Investig. 2018, 22, 69-80. [CrossRef] [PubMed] 
13. Mokcheh, A.; Jegham, H.; Turki, S. Short implants as an alternative to sinus lift for the rehabilitation of posterior maxillary atrophies: Systematic review and meta-analysis. J. Stomatol. Oral Maxillofac. Surg. 2019, 120, 28-37. [CrossRef] [PubMed]

14. Ergina, P.L.; Cook, J.; Blazeby, J.; Boutron, I.; Clavien, P.-A.; Reeves, B.C.; Seiler, C.M. Challenges in evaluating surgical innovation. Lancet 2009, 374, 1097-1104. [CrossRef]

15. Available online: https://collection.sciencemuseumgroup.org.uk/objects/co100246/bonwill-electromagnetic-mallet-automaticmallets (accessed on 13 December 2021).

16. Visale, K.; Manimala, V.; Vidhyasankari, N.; Shanmugapriya, S.V. Magnetic mallets-A stroke of luck in implantology: A review. J. Acad. Dent. Educ. 2021, 7, 6-9. [CrossRef]

17. Desai, A.; Patil, S.; Mitra, D.; Shah, R. Magnetic Mallet-Feel the Future. JIDA J. Indian Dent. Assoc. 2020, 14, 26-30. [CrossRef]

18. Liberati, A.; Altman, D.G.; Tetzlaff, J.; Mulrow, C.; Gøtzsche, P.C.; Ioannidis, J.P.A.; Clarke, M.; Devereaux, P.J.; Kleijnen, J.; Moher, D. The PRISMA statement for reporting systematic reviews and meta-analyses of studies that evaluate health care interventions: Explanation and elaboration. PLoS Med. 2009, 6, e1000100. [CrossRef]

19. Crespi, R.; Capparè, P.; Gherlone, E. Sinus floor elevation by osteotome: Hand mallet versus electric mallet. A prospective clinical study. Int. J. Oral Maxillofac. Implant. 2012, 27, 1144-1150.

20. Crespi, R.; Capparè, P.; Gherlone, E. A comparison of manual and electrical mallet in maxillary bone condensing for immediately loaded implants: A randomized study. Clin. Implant. Dent. Relat. Res. 2014, 16, 374-382. [CrossRef]

21. Crespi, R.; Capparè, P.; Gherlone, E.F. Electrical mallet in implants placed in fresh extraction sockets with simultaneous osteotome sinus floor elevation. Int. J. Oral Maxillofac. Implant. 2013, 28, 869-874. [CrossRef]

22. Crespi, R.; Capparè, P.; Gherlone, E. Electrical Mallet Provides Essential Advantages in Maxillary Bone Condensing. A Prospective Clinical Study. Clin. Implant. Dent. Relat. Res. 2012, 15, 874-882. [CrossRef]

23. Crespi, R.; Capparé, P.; Gherlone, E. Electrical mallet provides essential advantages in split-crest and immediate implant placement. Oral Maxillofac. Surg. 2013, 18, 59-64. [CrossRef]

24. Crespi, R.; Bruschi, G.B.; Capparé, P.; Gherlone, E. The utility of the electric mallet. J. Craniofac. Surg. 2014, 25, 793-795. [CrossRef]

25. Crespi, R.; Bruschi, G.B.; Gastaldi, G.; Capparé, P.; Gherlone, E.F. Immediate Loaded Implants in Split-Crest Procedure. Clin. Implant. Dent. Relat. Res. 2015, 17 (Suppl. 2), e692-e698. [CrossRef]

26. Crespi, R.; Capparè, P.; Crespi, G.; Gastaldi, G.; Gherlone, E.F. Delayed Implants Outcome in Maxillary Molar Region. Clin. Implant. Dent. Relat. Res. 2016, 19, 261-267. [CrossRef]

27. Crespi, R.; Capparé, P.; Crespi, G.; Gastaldi, G.; Gherlone, E. Bone-Level Changes Around Delayed Dental Implants in Previous Large Bone Defects Filled with Reactive Soft Tissue After Extraction: A Cone Beam Computed Tomography Study. Int. J. Oral Maxillofac. Implant. 2016, 31, 1429-1434. [CrossRef] [PubMed]

28. Crespi, R.; Capparé, P.; Crespi, G.; Gastaldi, G.; Gherlone, E.F. Dimensional Changes of Fresh Sockets with Reactive Soft Tissue Preservation: A Cone Beam CT Study. Implant. Dent. 2017, 26, 417-422. [CrossRef] [PubMed]

29. Menchini-Fabris, G.B.; Toti, P.; Crespi, G.; Covani, U.; Furlotti, L.; Crespi, R. Effect of Different Timings of Implant Insertion on the Bone Remodeling Volume around Patients' Maxillary Single Implants: A 2-3 Years Follow-Up. Int. J. Env. Res. Public Health 2020, 17, 6790. [CrossRef] [PubMed]

30. Menchini-Fabris, G.B.; Toti, P.; Crespi, G.; Covani, U.; Crespi, R. Distal Displacement of Maxillary Sinus Anterior Wall Versus Conventional Sinus Lift with Lateral Access: A 3-Year Retrospective Computerized Tomography Study. Int. J. Environ. Res. Public Health 2020, 17, 7199. [CrossRef]

31. Crespi, R.; Toti, P.; Covani, U.; Crespi, G.; Menchini-Fabris, G.-B. Clinical and Radiographic Evaluation of Modified Transalveolar Two-Step Osteotome-Mediated Localized Maxillary Sinus Elevation: A Retrospective Computed Tomography Study with a 3-Year Follow-up. Int. J. Oral Maxillofac. Implant. 2021, 36, 553-560. [CrossRef]

32. Bruschi, G.B.; Bruschi, E.; Papetti, L. Flapless Localised Management of Sinus Floor (LMSF) for trans-crestal sinus floor augmentation and simultaneous implant placement. A retrospective non-randomized study: 5-year of follow-up. Heliyon 2021, 7, e07927. [CrossRef]

33. Barone, S.; Antonelli, A.; Averta, F.; Diodati, F.; Muraca, D.; Bennardo, F.; Giudice, A. Does Mandibular Gonial Angle Influence the Eruption Pattern of the Lower Third Molar? A Three-Dimensional Study. J. Clin. Med. 2021, 10, 4057. [CrossRef]

34. Bakkar, M.; Liu, Y.; Fang, D.; Stegen, C.; Su, X.; Ramamoorthi, M.; Lin, L.-C.; Kawasaki, T.; Makhoul, N.; Pham, H.; et al. A Simplified and Systematic Method to Isolate, Culture, and Characterize Multiple Types of Human Dental Stem Cells from a Single Tooth. Methods Mol. Biol. 2017, 1553, 191-207. [PubMed]

35. Di Vito, A.; Giudice, A.; Chiarella, E.; Malara, N.; Bennardo, F.; Fortunato, L. In Vitro Long-Term Expansion and High Osteogenic Potential of Periodontal Ligament Stem Cells: More Than a Mirage. Cell Transpl. 2019, 28, 129-139. [CrossRef]

36. Jason, W.; Dan, H.; Nicholas, T. Powertome ${ }^{\circledR}$ Assisted Atraumatic Tooth Extraction. J. Implant. Adv. Clin. Dent. 2009, 1, 35-44.

37. Available online: https://www.osseotouch.com/en/products/easyroot/ (accessed on 13 December 2021).

38. Giudice, A.; Bennardo, F.; Antonelli, A.; Barone, S.; Fortunato, L. COVID-19 is a New Challenge for Dental Practitioners: Advice on Patients' Management from Prevention of Cross Infections to Telemedicine. Open Dent. J. 2020, 14, 298-304. [CrossRef]

39. Giudice, A.; Antonelli, A.; Bennardo, F. To test or not to test? An opportunity to restart dentistry sustainably in the 'COVID-19 era'. Int. Endod. J. 2020, 53, 1020-1021. [CrossRef] [PubMed]

40. Bennardo, F.; Antonelli, A.; Barone, S.; Figliuzzi, M.M.; Fortunato, L.; Giudice, A. Change of Outpatient Oral Surgery during the COVID-19 Pandemic: Experience of an Italian Center. Int. J. Dent. 2020, 2020, 1-6. [CrossRef] [PubMed] 
41. Chien, A.T.; Stehle, N.E.; Karian, B.K. The Use of Chisels in the Extraction of Mandibular Third Molars: A Technique That May Prevent the Aerosolization of Severe Acute Respiratory Syndrome Coronavirus 2. J. Oral Maxillofac. Surg. 2021, 79, 1199-1206. [CrossRef]

42. Hong, J.-Y.; Shin, E.-Y.; Herr, Y.; Chung, J.-H.; Lim, H.-C.; Shin, S.-I. Implant survival and risk factor analysis in regenerated bone: Results from a 5-year retrospective study. J. Periodontal Implant. Sci. 2020, 50, 379-391. [CrossRef]

43. Cha, J.K.; Kim, C.; Pae, H.C.; Lee, J.S.; Jung, U.W.; Choi, S.H. Maxillary sinus augmentation using biphasic calcium phosphate: Dimensional stability results after 3-6 years. J. Periodontal Implant. Sci. 2019, 49, 47-57. [CrossRef] [PubMed]

44. Toti, P.; Barone, A.; Marconcini, S.; Fabris, G.B.M.; Martuscelli, R.; Covani, U. Pose determination of a blade implant in three dimensions from a single two-dimensional radiograph. Dentomaxillofacial Radiol. 2018, 47, 20170258. [CrossRef] [PubMed]

45. Feher, B.; Frommlet, F.; Gruber, R.; Hirtler, L.; Ulm, C.; Kuchler, U. Resonance frequency analysis of implants placed in condensed bone. Clin. Oral Implant. Res. 2021, 32, 1200-1208. [CrossRef] [PubMed] 